\title{
NEW APPROACHES OF THE HYPONATREMIA TREATMENT IN THE ELDERLY - AN UPDATE
}

\author{
ALICE BĂLĂCEANU ${ }^{1,2 \#, ~ S E C I L ~ O M E R ~}{ }^{1,2}$, SILVIU ADRIAN MARINESCU ${ }^{1,3 *}$, SILVIU MIREL \\ PITUURU $^{1 \#}$, ȘERBAN DUMITRACHE ${ }^{2 \#}$, DANIELA ELENA POPA ${ }^{1}$, ANDREEA ANTONIA \\ GHEORGHE $^{2}$, SIRAMONA POPESCU ${ }^{3}$, CĂTĂLIN BEJINARIU ${ }^{3}$, OCTAV GINGHINĂ ${ }^{1,2}$, \\ CARMEN GIUGLEA ${ }^{1,2}$
}

1 "Carol Davila” University of Medicine and Pharmacy, 37 Dionisie Lupu Street, 020021, Bucharest, Romania

2 "Sf. Ioan” Clinical Emergency Hospital, 13 Vitan-Bârzești Road, 042122, Bucharest, Romania

3 “Bagdasar Arseni” Clinical Emergency Hospital, 12 Berceni Road, 041915, Bucharest, Romania

*corresponding author: silviumarinescu@hotmail.com

${ }^{\#}$ Authors with equal contribution.

Manuscript received: December 2019

\begin{abstract}
Hyponatremia (hNa) is a frequently common imbalance in the elderly hospitalized patients. It is often correlated with elevated plasma quantities of arginine vasopressin (AVP, the antidiuretic hormone) and namely it depicts a water surplus in order to prevail sodium levels. It can conduct, in a comprehensive range, to detrimental changes that can affect the entire health status, especially the central nervous system, thus increasing the mortality and morbidity of hospitalized patients in care units. The inherent treatment of $\mathrm{hNa}$, mainly of the chronic form, requires the correction of serum sodium concentrations at the appropriate rate, because, augmenting it at a warp speed, it can determine permanent or fatal neurologic sequelae. In this regard, the therapy for hNa may be enlightened by egressing therapies that include vasopressin V2 and V1a receptors antagonists, with the principal role of encouraging aquaresis and rise the serum sodium levels, alongside with the electrolytesparing discharge of free water.
\end{abstract}

\section{Rezumat}

Hiponatremia este o afecțiune frecvent întâlnită la pacienții vârstnici. Este asociată adesea cu un nivel plasmatic ridicat de arginină vasopresină (hormon antidiuretic) și adesea, definește excesul de apă în raport cu depozitele de sodiu predominante. Poate determina o serie largă de modificări periculoase, care implică în special sistemul nervos central, crescând morta litatea și morbiditatea pacienților spitalizați. Tratamentul corespunzător al hiponatremiei, în special al formei cronice, implică corectarea concentrațiilor serice de sodiu la un nivel corespunzător, deoarece, în caz contrar, pot să apară sechele neurologice permanente sau fatale. Tratamentul hiponatremiei poate fi facilitat de terapii inovatoare care blochează acțiunile vasopresinei asupra receptorilor vasopresinei V2 și V1a pentru a favoriza excreția apei fără electroliți și a crește concentrațiile serice de sodiu.

Keywords: sodium, hyponatremia, vasopressin, vaptans

\section{Introduction}

Homeostatic mechanism involving renal control, craving, arginine vasopressin (AVP, the antidiuretic hormone) and water rendition [1] are responsible for maintaining the sodium concentration in plasma within a relatively narrow range [2]. When modifications occur in any of these essential segments, towards the control water balance, hyponatremia $(\mathrm{hNa})$ becomes evident, revealing a commonly condition that pose many challenges [2], despite his apparent small clinical expression, by significantly amplifying the morbidity and mortality, alongside hindering the course of an accompanying disease [2, 3]. This review aims to express the theoretical aspects of the prevailing form of $\mathrm{hNa}$, especially in elders, and to underline the great importance of a proper pharmacological treatment.

\section{Hyponatremia - at a glance}

We acknowledge three types of hNa: mild (serum sodium concentration is found between 130 and 134 $\mathrm{mEq} / \mathrm{L}$ ), moderate (serum sodium concentration average between 125 and $129 \mathrm{mEq} / \mathrm{L}$ ) and severe (sodium concentration limit is $<125 \mathrm{mEq} / \mathrm{L}$ ). In either case, it can embrace an acute (developed in less than 48 hours) or a chronic form (more or equal to 48 hours). With respect to an emerging cerebral oedema accompanying hNa stated in less than $48 \mathrm{~h}$, current literature data underlines as a limit the time of 48 hours to perceive between acute and chronic hNa [4]. Experimental studies support the information according to which the brain requires almost $48 \mathrm{~h}$ to adapt to a hypotonic habitat, accomplished principally through the extrusion of sodium, chloride, potassium, 
and organic osmoles from its cells [5]; in advance to such adjustment, within the brain, always a damage occurs, e.g. the risk of cerebral oedema. Yet, once the adaptation is performed, an injury of the myelin sheath enclosing individual neurons can trigger in the osmotic demyelination syndrome [6], which is a rare, but dramatic drawback in chronic hNa, mainly due to rapid correction [7] of the serum sodium level. This fact explains the relevance, in the clinical practice, of recognising the acute or the chronic form [5] of the hNa, judging whether the possible risk occurred entails cerebral oedema or osmotic demyelination. Unless there are reasons to think otherwise, if there are questions arising about the progress of the $\mathrm{hNa}$ [5-7], it should be assessed chronic. Also, whether moderate or severe, the most important based plasma osmolality [8-11] is the volume status, which leads to the main three forms of $\mathrm{hNa}$. The hypotonic hyponatremia [4] is a condition defined by water displacement from the extracellular area to the intracellular area, due to decreased extracellular sodium attended by extracellular fluid hypotonia and cellular oedema. Frequently, the inappropriate secretion of the antidiuretic hormone syndrome (SIADH) is incriminated (Figure 1) [12, 13]. The nonhypotonic hyponatremia (isotonic or hypertonic) [4], as a dilutional $\mathrm{hNa}$ [14], is generated by the accumulation of effective osmoles in the plasma concentration, replacing the water from the intracellular to the extracellular extent $[14,15]$. According to the concentration of the plasma compounds, normal or enhanced values of the osmolality may be depicted (Figure 1). Hyperglycaemia is frequently the cause [16]. The fictional hyponatremia or pseudohyponatremia stands for a large gathering of lipids or proteins, in conditions of normal plasma osmolality, but with falsely diminished sodium plasma concentration [5, 17 - 19].

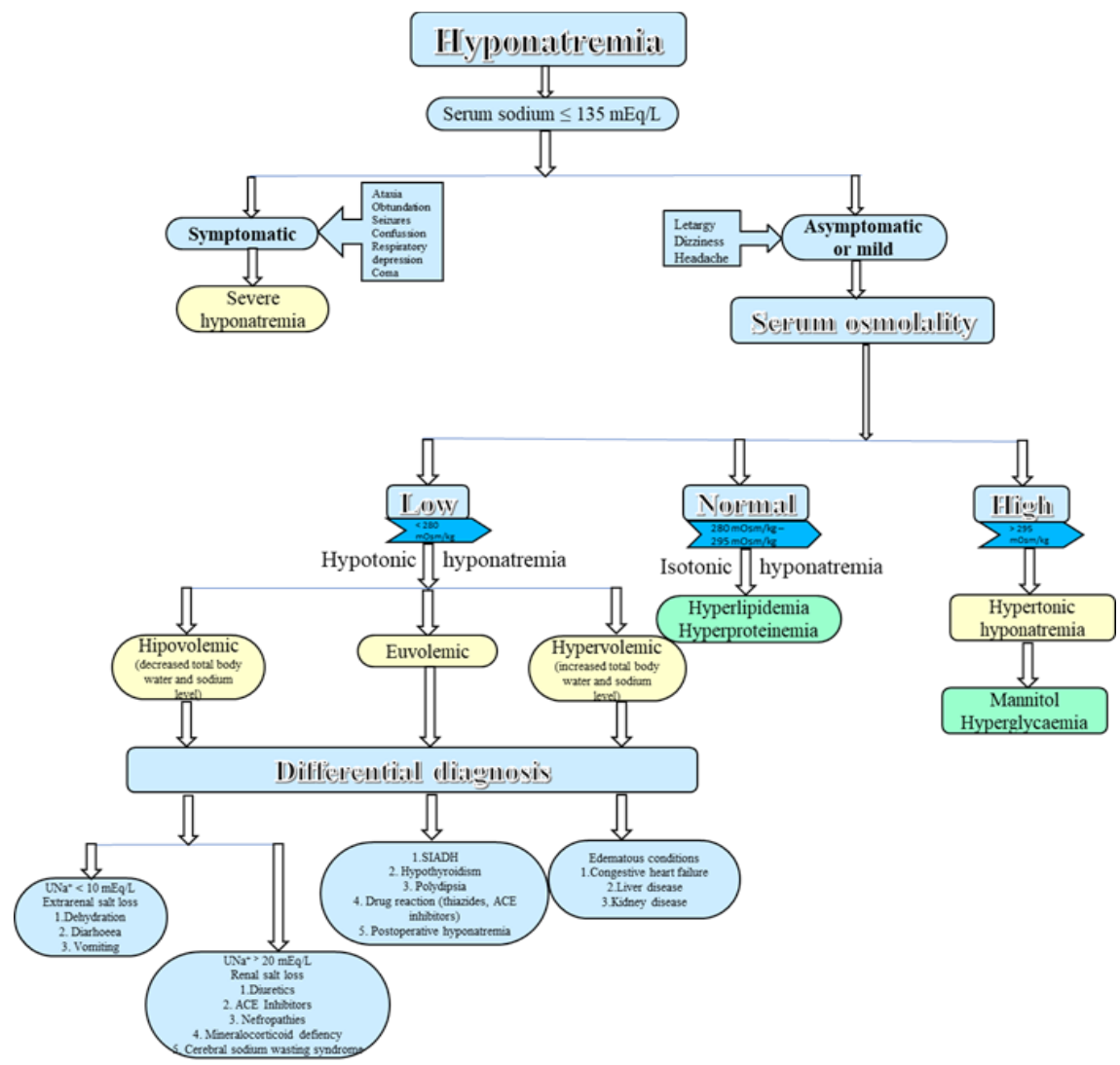

Figure 1.

Aetiology of hyponatremia

By surveilling the literature date, it can be disclosed a relation encountered with the psychotropic drugs, especially on account of the inadequate discharge of the antidiuretic hormone, $\mathrm{ADH}$, that mediates the $\mathrm{hNa}$ $[20,21]$. ADH, the hypothalamic peptide, is hold and released through the neurohypophysis [4], playing a key role in the management of the total body water, as an osmotic and non-osmotic stimuli-response [22]. The vasopressin effects are mediated by stimulating the tissue-specific G protein-coupled receptors (GPCRs) also named the vasopressin receptors: V1 (exhibits vasopressor effect), V2 (reliable for the reabsorption of the water in the nephron collecting tubules) and V3 (accountable for the ACTH release). ADH has two principal functions [4]. Firstly, renal - after its release from the posterior pituitary gland, it binds to the type-2 receptor (V2) in the collecting duct principal cells. Following an intracellular cyclic adenosine mono- 
phosphate (cAMP) pathway after binding to the receptor, the phosphorylation of the aquaporin-2 (AQP2) occurs. The result is the decrease of the ADH levels, alongside with the water homeostasis, and AQP2 is internalized from the plasma membrane, leaving it watertight again [23]. In the nephron, AQP2 controls the apical water permeability and it is expressed exclusively in the collecting duct principal cells [4].
Due to the ADH-depending activity, the response is released to hyperosmolar and hypovolemic stimuli (Table I). In this direction, a kind of passed-on nephrogenic diabetes insipidus correlated with some genetic AQP2 disorders is investigated [4, 22]. Secondly, in the vascular smooth muscle, it is responsible for vaso-constriction and enlarges peripheral vascular endurance $[4,23,24]$.

Table I

Vasopressin receptors subtype, location, functions, and non-peptide antagonists

\begin{tabular}{|c|c|c|c|c|c|c|}
\hline \multicolumn{2}{|c|}{\begin{tabular}{|c|c|}
\multicolumn{2}{|c|}{ Receptor subtype } \\
IUPHAR & alternate \\
\end{tabular}} & Location & Physiological effect & $\begin{array}{l}\text { Non-peptide } \\
\text { antagonist }\end{array}$ & Clinical progress & $\begin{array}{l}\text { Signalling } \\
\text { pathways }\end{array}$ \\
\hline \multirow[t]{6}{*}{ V1a } & \multirow[t]{6}{*}{ V1 } & $\begin{array}{c}\text { vascular smooth } \\
\text { muscle }\end{array}$ & $\begin{array}{c}\text { vasoconstriction, myocardial } \\
\text { hypertrophy }\end{array}$ & Relcovaptan & $\begin{array}{l}\text { Raynaud's } \\
\text { syndrome }\end{array}$ & \multirow{6}{*}{$\begin{array}{c}\text { G protein- } \\
\text { coupled, } \\
\text { phosphatidyl- } \\
\text { inositol/calcium }\end{array}$} \\
\hline & & hepatocyte & glycogenolysis & & & \\
\hline & & platelet & platelet aggregation & & & \\
\hline & & myometrium & uterine contraction & Relcovaptan & dysmenorrhoea & \\
\hline & & renal & $\begin{array}{c}\text { prostaglandin synthesis } \\
\text { stimulation, decrease in inner } \\
\text { renal blood flow, glomerular } \\
\text { mesangial contraction }\end{array}$ & & & \\
\hline & & adrenal & $\begin{array}{l}\text { stimulation of aldosterone and } \\
\text { cortisol secretion }\end{array}$ & $\begin{array}{l}\text { OPC-21268 } \\
\text { (Fuscoside) }\end{array}$ & \begin{tabular}{|c|} 
ACTH-independent \\
macronodular \\
adrenal hyperplasia
\end{tabular} & \\
\hline \multirow[t]{2}{*}{ V1b } & \multirow[t]{2}{*}{$\mathbf{V 3}$} & $\begin{array}{c}\text { corticotrophin } \\
\text { cells and anterior } \\
\text { pituitary } \\
\end{array}$ & releases ACTH, endorphins & Nelivaptan & & \multirow{2}{*}{$\begin{array}{c}\text { G protein- } \\
\text { coupled, } \\
\text { phosphatidyl- } \\
\text { inositol/calcium }\end{array}$} \\
\hline & & brain & stress adaptation & $\begin{array}{l}\text { SSR-149415 } \\
\text { (Nelivaptan) }\end{array}$ & depressive disorders & \\
\hline \multirow[t]{7}{*}{$\mathbf{V 2}$} & \multirow[t]{7}{*}{$\mathbf{V 2}$} & \multirow{5}{*}{$\begin{array}{l}\text { cells membrane } \\
\text { of the collecting } \\
\text { ducts }\end{array}$} & \multirow{5}{*}{$\begin{array}{l}\text { intromission of AQP-2 water } \\
\text { channels into apical } \\
\text { membrane and thus water } \\
\text { reabsorption, grounding the } \\
\text { AQP-2 synthesis }\end{array}$} & Mozavaptan & only SIADH & \multirow{7}{*}{$\begin{array}{c}\text { Adenylyl } \\
\text { cyclase/cAMP }\end{array}$} \\
\hline & & & & Lixivaptan & $\begin{array}{l}\text { SIADH, cirrhosis, } \\
\text { CHF }\end{array}$ & \\
\hline & & & & Conivaptan & $\begin{array}{c}\text { hyponatraemia, } \\
\text { CHF }\end{array}$ & \\
\hline & & & & Satavaptan & $\begin{array}{c}\text { hyponatraemia, } \mathrm{CHF}, \\
\text { ascites formation } \\
\text { prophylaxis }\end{array}$ & \\
\hline & & & & Tolvaptan & $\begin{array}{l}\text { hyponatraemia, } \\
\text { CHF, polycystic } \\
\text { kidney disease }\end{array}$ & \\
\hline & & $\begin{array}{c}\text { vascular } \\
\text { endothelium }\end{array}$ & releases vWF and factor VIII & & & \\
\hline & & $\begin{array}{l}\text { vascular smooth } \\
\text { muscle cell }\end{array}$ & vasodilation & & & \\
\hline
\end{tabular}

IUPHAR - International Union of Basic and Clinical Pharmacology; cAMP - cyclic adenosine monophosphate; ACTH - adrenocorticotropic hormone; AQP-2 - aquaporine-2; CHF - chronic heart failure; vWF - von Willebrand factor.

\section{Dispersion of hyponatraemia in the elderly}

$\mathrm{hNa}$ in the elderly, similar to the general population, presents different variations, mainly depending on both the risk population and sodium concentration used to ascertain $[3,12,24]$ this disorder and the frameworks in which the analysis is performed. Although there is a common used "normal range" for the serum sodium levels (135 - $142 \mathrm{mEq} / \mathrm{L})$, regarding the U-shaped correlation between serum sodium concentration and mortality, other exact types of hNa have been suggested $[3,25,26]$. In this context, the dispersion of hNa was pronounced in the 75 years of age subjects, comprising $11.6 \%$ of subjects in a population-based Rotterdam study [3]. In health care settings, the reduced serum sodium levels [3] are retrieved. For example, Miller et al. [27], in a nursing home population study, underlined that $18 \%$ of subjects aged 60 encountered $\mathrm{hNa}$ (defined by serum sodium concentrations, under the value of $130 \mathrm{mmol} / \mathrm{L}$ ). Additionally, in a 12 months period of performing serum sodium multiple analyses, at any rate, one event of $\mathrm{hNa}$ was observed in almost a moiety of patients [3]. Likewise, in another prospective study, aiming hospitalized patients aged 65 years and more, the percentage of encountering low serum sodium levels, under $135 \mathrm{mEq} / \mathrm{L}$, covered a third of the subjects [3, 28]. 
FARMACIA, 2020, Vol. 68, 3

When observing the orthostatic hypotension risk factors in a healthy cohort, Caird et al. noticed that almost $7 \%$ of subjects [25] in the age of 65 years and older presented serum sodium levels under $137 \mathrm{mEq} / \mathrm{L}$ [29]. By contrary, among a long-term care facility subjects, the spreading of $\mathrm{hNa}$ was approximatively $20 \%$, setting for the serum sodium concentration an endpoint value beneath $135 \mathrm{mEq} / \mathrm{L}[30,31]$.

Not for the least, researchers included, in a recent study, patients with lower respiratory tract infection (LRTI), intending to disclose the occurrence of $\mathrm{hNa}$ in elderly. The study took into account the three encountered types of decrements for serum sodium concentration: mild (131 - $135 \mathrm{mmol} / \mathrm{L})$, moderate $(126-130 \mathrm{mmol} / \mathrm{L})$ and severe decrements $(<126$ $\mathrm{mEq} / \mathrm{L})[32]$. The prevalence of hNa among elderly raised to the considerable percent of $45 \%$ patients [25] with associated pathologies, regardless the age, sex, and type of LRTI [32]. More than 300,000 samples were collected from more than 120,000 patients. Even though the reference group comprised $\mathrm{a} \leq 30$-year-old cohort and the principal end-point was the serum sodium value $<136 \mathrm{mEq} / \mathrm{L}$, the prevalence of $\mathrm{hNa}$ in subjects over 60 years was significantly higher at admission and also as a hospital-acquired disease [25, 33-36].

\section{Mechanisms of a rising sensitiveness of the elderly to enhance hyponatremia}

The main presumption of the elderly to evolve in a $\mathrm{hNa}$ condition is correlated with the weaken waterexcretory capacity due to age, and the associated $\mathrm{hNa}$ diseases [3] and other pathologies linked medications. In elderly patients, a large scale of factors is commonly involved in the headway of $\mathrm{hNa}$. This water-excretory capacity particularly assigned to the reduction of the glomerular filtration rate (GFR) age-correlated is more popular in elders developing hNa $[3,25,36]$. Additionally, it could be involved a mechanism which implies a lowest intrarenal prostaglandins generation production encountered in advanced age [3, 37]. Nevertheless, the total body water content age-related reduction is conducting to abnormal variations of serum sodium levels, because the serum sodium concentration is formed of the total exchangeable sodium and potassium, reported to the total body water, as the Edelman equation $[36,38]$ depicts (Figure 2).

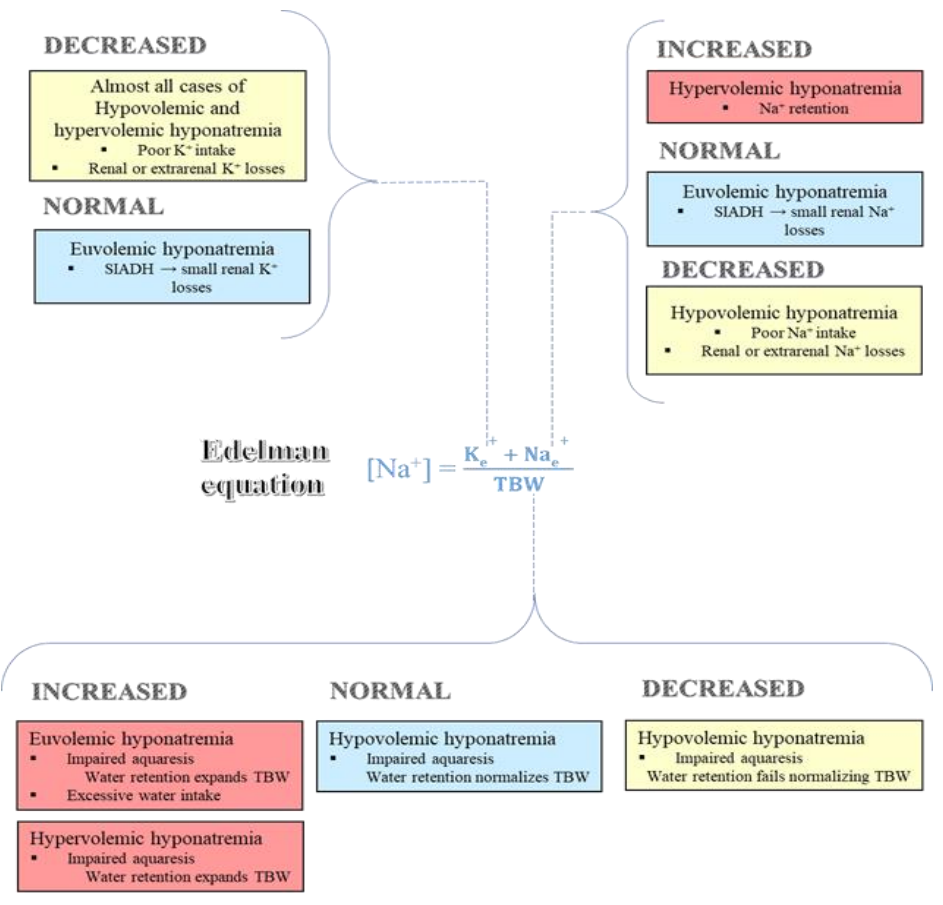

Figure 2.

Hyponatremia pathogenesis following the water excess in relation with the body's sodium and potassium concentrations (TBW - total body water; $\mathrm{K}_{\mathrm{e}}^{+}-$exchangeable potassium; $\mathrm{Na}_{\mathrm{e}}{ }^{+}-$exchangeable sodium)

Moreover, in geriatric population [3] it is more often assessed as relatively rare the idiopathic SIAD [12, 13]. But, regarding the elderly population, there is acknowledged a preserved urinary diluting ability [3], even with a low GFR, and the factors involving an emerging hNa are in agreement with a high amount of water consumption, along with other ardent or/and overlying factors [3], among which some are below presented.

\section{Drugs}

In the discussed context, elderly persons frequently take drugs, among which stand out non-steroidal antiinflammatory drugs (NSAIDs) [3], serotonin-nor- 
epinephrine reuptake inhibitors (SNRIs), selective serotonin reuptake inhibitors (SSRIs) [35], thiazide diuretics and/or undergo different associated pathologies (e.g., endocrinopathies, diabetes mellitus (DM), liver diseases, heart failure, tumours, infections) [39] that support today the $\mathrm{hNa}$ causes. Among these present additional low serum sodium levels risk factors [39], the $\mathrm{hNa}$ incidence induced by thiazides has not yet distinctly fulfilled the blanks. Besides, within a population of patients with thiazide medication [3], approximatively $14 \%$ had $\mathrm{hNa}$, whereas patients aged more than 65 years were linked with a fourfold rising of the $\mathrm{hNa}$ risk [41]. In the neurological field, in patients aged 60 years and older, receiving SSRIs, SNRIs and mirtazapine, the hNa cases have an ascending slope. Drugs like bupropion, trazodone and tricyclic antidepressants are less incriminated in the $\mathrm{hNa}$ aetiology [40]. Moreover, many elderly have cardiac pathologies or low-salt diet due to heart failure [3, 39-42], along with a reduced protein intake diet (customised or due to overlapped disorders) that hinders water elimination and translates into low serum sodium concentrations, leading to another clue for the evolution of hNa [43, 44]. Also, it is valuable the observation regarding the seasonal variation of $\mathrm{hNa}$ (with a higher occurrence during the summer) because of more obvious increased water ingestion, distortion of renal function, increased sodium chloride deprivation, reduced sodium chloride intake [3, 25, 45]. Low body mass index, female gender, concomitant non-psychiatric medication administration, such as NSAIDs, PPIs (proton-pump inhibitors), diuretics, angiotensin-converting enzyme inhibitors [41], likewise as the attendance of heart injury, adrenal insufficiency or liver disorders are encouraging features that explain the associated $\mathrm{hNa}$ in the elders treated with psychotropic medications [42]. Antiepileptic drugs (AEDs), e.g. carbamazepine and oxcarbazepine acetate are prevailing $\mathrm{hNa}$ [46, 47]. Lately, other AEDs, such as lamotrigine, gabapentin, eslicarbazepine, levetiracetam and sodium valproate, have also been claimed to render hNa. Properly, phenytoin, topiramate and valproic acid have been incriminated with a pronounced threat of producing $\mathrm{hNa}$ in patients being hospitalized in comparison with those who did not pursuit an AEDs treatment [3, 25-27, 47, 48].

\section{SIADH}

Expanded plasma vasopressin concentrations acts like an escort for aging $[3,7,12,49]$. Researchers were preoccupied to enlist patients at the age of 65 years and even older in clinical trials and mostly found SIAD in half of subjects $[3,50]$ with hNa. This syndrome was the leadership reason that entails severe hyponatremia in elderly hospitalized patients. It is to note that the relatively rare idiopathic SIAD discloses a high percentage among the elderly, related to pain, mild hypovolemia, and orthostatic hypotension. Also, several types of cancers cause excessive production of $\mathrm{ADH}$ leading to SIADH [51].

\section{Endocrine dysfunctions}

With regard to patients over 65 years of age or older, hypopituitarism it should not be evaluated as a scare source of developing hNa [3]. Ishikawa et al. described that $40 \%$ of this hyponatraemic patients, with signals like weakness or fatigability, have pituitary adrenal dysfunction [3, 49, 52]. Nevertheless, diabetes mellitus (DM) ranks between the first positions among the seniors. During marked episodes of hyperglycaemia, considering glucose as an osmotic active substance, able to take out the water from cells and afterwards to diminish serum sodium levels by dilution, serum osmolality (Posm) is increased. In the case of uncontrolled DM, assessed hypovolemia is nearly an invariable exposure due to hypotonic liquid losing, in excess of electrolytes, and osmotic diuresis. This, followed by an extensive ingestion of hypotonic solutions or water (without solutes), may be a possible cause for $\mathrm{hNa}[3,52,53]$. Noticeable, there is a correlation between $\mathrm{DM}$ and $\mathrm{hNa}$ regardless of the attendance of hyperglycaemia [51, 54].

\section{"Tea and toast" hyponatremia}

A salt and protein poor diet, but linked with a large volume of water, transpose this type of $\mathrm{hNa}$ into an accountable condition in elders with a low GFR [3, $33,36]$. In these cases, it follows an increased water reabsorption and a low filtrate distal transportation (due to modest GFR and presumably persistent sodium loss), suitable for a low rate of osmoles excretion. Also, when renal water excretion capacity is surpassed by the water consumption, hNa occurs [33, 55, 57].

\section{General recommendations for treatment}

\section{Water Restriction}

Although this pathogenesis involves water retention and the kidney's remissive capacity to eliminate it, the headstone of the chronic $\mathrm{hNa}$ treatment has been the water intake restriction [25]. However, such restriction is barely endured over time and the compliance with significant water restriction is problematic. The fluid intake $[2,7]$ is not driven by thirst, but rather is appointed by habits or other facets. Water intake restriction is often strongly supported [25], in the absence of any scientific support. Furthermore, when it is present a severe diluting defect, water restriction is not always a solution, particularly. As presented by Furst et al. [44], when the total amount of urinary potassium and sodium concentrations overruns the serum sodium concentration, the water without electrolytes is not excreted and that explains why none of the 
water restriction volume [25] will determine an enhancement in the serum sodium concentration.

\section{Demeclocycline}

After vasopressin binds to the V2 receptor, inhibiting the adenylate cyclase activity [27], this drug aims the mechanism fulfilling the enquiring water-retaining pathogenesis states. In case of water restriction or nottreatable cause of $\mathrm{hNa}$, the usual range dose is between 900 and $1200 \mathrm{mg} /$ day. The response rate is extremely variable [25]. This agent acknowledges severe gastrointestinal side effects, photosensitivity, nephrotoxicity, augmented by co-pathologies like liver diseases [58]. Demeclocycline is not officially authorised by Food and Drug Administration (FDA) for the treatment of hNa [25], mainly due to the nephrotoxic effect.

High ceiling diuretics and $\mathrm{NaCl}$

Dietary intake is supplemented with the administration of 2 - $3 \mathrm{~g}$ daily of $\mathrm{NaCl}$, in order to prevent concomitant unwanted sodium depletion. The scientific explanation for the loop/high ceiling diuretics therapy and $\mathrm{NaCl}$ supplementation binds with the capacity of these drugs to encourage the electrolyte-free water excretion. The $\mathrm{NaCl}$ intake and excretion will rise the solute delivery which translates into an enhancement of the electrolyte free water clearance. Additionally, potassium repletion [5, 36, 38, 44] or potassium-saving diuretic medication is also often required for escaping from the clinically considerable hypokalaemia. Although this pharmaceutical manner has been widely used in the symptomatic hNa treatment, the literature data arise one case treated successfully for 6 months [59].

\section{Urea}

Administering urea in a dose range of 30 - $50 \mathrm{~g} /$ day can achieve the goal of augmenting serum sodium concentration in chronic hNa patients [25], by lowering the urinary sodium and potassium concentrations and consequently rising the elimination of water without electrolytes, by increasing urine flow rate [59-61]. Although a recent study by Soupart et al. [62] described that urea has been effective in increasing serum sodium levels with a high degree of tolerability, as the vasopressin antagonist tolvaptan, in 13 patients with SIADH [61], the main reason the for not using urea is because of his poor palatability connected with his own poor adherence. Although urea [25] has two main advantages, that is a low cost and is potentially effective, patients do not tolerate this drug because of its taste. So, we can assume it can be considered a second line treatment option.

Vaptans (Vasopressin Receptor Antagonists) regulating water excretion drugs

Vaptans bind to the V2 receptor and therefore block $\mathrm{ADH}$, leading to aquaresis electrolyte [37] or free diuresis. In hyponatraemic patients, the serum sodium concentrations are elevated because of the aquaresis (acquired nephrogenic diabetes insipidus). In this regard, vasopressin has not the appearance to unfold important physiologic or pathophysiologic effects via the V1 receptors. Tolvaptan, mozavaptan, lixivaptan and satavaptan are drugs that specifically block the V2 receptor, while conivaptan is a non-specific blocker of both the V2 and the V1a [37] receptors. In the United States, only tolvaptan and conivaptan are available for clinical use, instead, satavaptan has been withdrawn for further research (it was correlated with a higher mortality, especially in patients with cirrhosis, that is when diuretics are a must and the treatment is for long term [63]) and lixivaptan has not been discharged for clinical use [64]; in Japan, mozavaptan has been authorized for the treatment of SIADH. Taking into consideration the administration pathways, conivaptan is available only as an intravenous drug, recorded as a benefit for the hospitalised critically ill patients [49, 65]. The oral preparations are included in therapy, but it is acknowledged their potency as inhibitors of the cytochrome P450 3A4 [37] system, leading to many drug-drug interactions [24, 47, 48, 61-64]. As earlier recalled, only conivaptan binds likewise to V1a and V2 receptors, whereas the other vaptans develop a higher specificity for the V2 receptors (Table II). Although, the pharmacokinetic and pharmacodynamic profiles are still limited, these agents are rather different in the backgrounds of bioavailability, peak urinary effect, time to peak plasma concentration and clearance halftime after oral [66] administration. In hospitalized patients, in the treatment scheme of the clinically significant euvolemic and hypervolemic hNa, the intravenous conivaptan and oral tolvaptan have been stated [67].

Table II

Vaptans used in clinical trials

\begin{tabular}{|l|c|c|c|c|c|}
\hline & OPC-41061 & YM-087 & VA-985 & SR-121463-B & OPC-31260 \\
\hline Drug name & Tolvaptan & Conivaptan $^{\text {Lixivaptan }}$ & Satavaptan & Mozavaptan \\
\hline Trade name & Samsca $^{\circledR}$ & Vaprisol $^{\circledR}$ & ------ & Aquilda $^{\circledR}$ & Physuline $^{\circledR}$ \\
\hline Drug status & $\begin{array}{c}\text { Approved by FDA for } \\
\text { SIADH, CHF, cirrosis; } \\
\text { Approved by EMEA for } \\
\text { SIADH }\end{array}$ & $\begin{array}{c}\text { Approved by } \\
\text { FDA for hypo- } \\
\text { volemic and } \\
\text { euvolemic hNa }\end{array}$ & $\begin{array}{c}\text { Phase III } \\
\text { Clinical trial }\end{array}$ & $\begin{array}{c}\text { Withdrawn in } \\
2008 \text { by the } \\
\text { manufacturer }\end{array}$ & $\begin{array}{c}\text { Approved in } \\
\text { Japan for SIADH } \\
\text { secondary to } \\
\text { malignancy }\end{array}$ \\
\hline $\begin{array}{l}\text { Development } \\
\text { laboratory }\end{array}$ & Otsuka & $\begin{array}{c}\text { Yamanouchi } \\
\text { Astellas }\end{array}$ & $\begin{array}{c}\text { Wyest-Ayerst } \\
\text { (Pfizer) Cardiokine }\end{array}$ & Sanofi Aventis & Otsuka \\
\hline Core & Benzazepine & Benzazepine & Benzazepine & $\begin{array}{c}\text { N-arylsulfonyl- } \\
\text { oxindole }\end{array}$ & Benzazepine \\
\hline
\end{tabular}


FARMACIA, 2020, Vol. 68, 3

\begin{tabular}{|c|c|c|c|c|c|}
\hline & OPC-41061 & YM-087 & VA-985 & SR-121463-B & OPC-31260 \\
\hline Administration route & Oral & iv & Oral & Oral/iv & Oral \\
\hline Dose & $7.5-15-60 \mathrm{mg} /$ day & $40-80 \mathrm{mg} /$ day & $\begin{array}{c}50-100 \mathrm{mg} \\
\text { twice/day }\end{array}$ & $5-25 \mathrm{mg} /$ day & $30-60 \mathrm{mg} /$ day \\
\hline Protein binding & $>98 \%$ & $98 \%$ & $>98 \%$ & $<90 \%$ & \\
\hline Half-life (hours) & $6-8$ & $3-8$ & $7-10$ & $15-17$ & \\
\hline Receptors blocked & $\mathrm{V} 2$ & $\mathrm{~V} 1+\mathrm{V} 2$ & $\mathrm{~V} 2$ & $\mathrm{~V} 2$ & $\mathrm{~V} 2$ \\
\hline Metabolism & CYP3A4 & CYP3A4 & CYP3A4 & $\begin{array}{l}\text { CYP3A4 } \\
\text { CYP2D6 }\end{array}$ & CYP3A4 \\
\hline Elimination & \multicolumn{5}{|c|}{ Faeces } \\
\hline
\end{tabular}

The safety profile of the vaptans acknowledge as primary adverse effect thirst. Every so often, vaptans have been noticed to increase the sodium levels in plasma in a faster manner than it is registered to shun the osmotic demyelination [6], a possible complication that was not reported in any clinical trial [68] performed on vaptans. Nevertheless, clinicians have pursuit the vaptan therapy with the use of fluid restriction [6264], leastways during the initial $24 \mathrm{~h}$, although the most common described adverse effect is thirst and also because the increased liquid consumption may counterbalance the wished effect regarding the plasma sodium levels. These should be closely observed during treatment and in the same manner used to conduct any decision regarding the fluid intake and continued dosing. Mild chronic hNa [37] (average serum sodium around $130 \mathrm{mEq} / \mathrm{L}$ ) was the main inclusion criteria for enrolling subjects in the randomized controlled trials (Table III) conducted with vaptans. The possible explanation for not including symptomatic severe chronic $\mathrm{hNa}$ patients in these trials [37] entail the ethical requirements, meaning the patients from the placebo arm would be injured. A placebo-controlled randomized trial performed with intravenous conivaptan [37], on hospitalized asymptomatic patients with euvolemic and hypervolemic hyponatremia, revealed the safety and efficacy of this drug (serum sodium 115 to $0.5 \mathrm{mEq} / \mathrm{L} / \mathrm{h}$ in the first day of research) [69]. Osmotic demyelination as a possible adverse event was not described. The efficacy and the safety of tolvaptan were demonstrated in the vasopressin antagonism in heart failure trial - EVEREST ("The Effects of Oral Tolvaptan in Patients Hospitalized for Worsening Heart Failure") [70]. This vaptan was the drug administered to 2072 hospitalized patients [37] and diagnosed with decompensated heart failure, the result being a marked enhancement of serum sodium levels for the patients with $\mathrm{hNa}$, even though that was not an inclusion criterion. Two osmotic demyelination post marketing reports [37] have been highlighted when tolvaptan was administered for correcting $\mathrm{hNa}$ with hypertonic saline. As revealed by the TEMPO trial ("Tolvaptan Efficacy and Safety in Management of Autosomal Dominant Polycystic Kidney Disease and its Outcomes") [37, 71], in which the focus was the prevention of gradual renal failure in patients with polycystic kidney disease, FDA has expressed an advertisement not to administrate tolvaptan to liver associated pathology patients (the liver enzymes have evidenced an 2.5-fold increase reported to placebo) and has also restricted the employment time to 30 days [37]. It should be emphasised that the trial was conducted with significant higher doses (60 - $120 \mathrm{mg} / \mathrm{day}$, modal $90 \mathrm{mg} /$ day) as against the most used doses in the hNa clinical trials (maximum $60 \mathrm{mg} /$ day). On the other hand, in the SALT ("Study of Ascending Levels of Tolvaptan in Hyponatremia") tolvaptan clinical trial [37, 72], in euvolemic patients, the increase in serum sodium concentration on the first 24 hours of drug administration [25], in the tolvaptan group, was $5.60 \mathrm{mEq} / \mathrm{L}$, towards $7.45 \mathrm{mEq} / \mathrm{L}$ in a trial with conivaptan [25], and respectively $6.29 \mathrm{mEq} / \mathrm{L}$ in a comprehensive meta-analysis [73]. Going through this meta-analysis involving the hypervolemic patients, although the recorded response was unpretentious, at $4.09 \mathrm{mEq} / \mathrm{L}$, there is to note the adverse effects, correlated particularly to the aquaretic involving drugs effects: polyuria, dry mouth, nocturia and thirst [25]. Nonetheless, the final goal would be the increase of serum sodium concentrations with $5-7 \mathrm{mEq} / \mathrm{L}$ in the first 24 hours, and free access to water should be permitted to patients in order to reduce excessive correction ratios [25, 27, 30-33]. Studying hyponatraemic subjects inside of larger ongoing placebo-controlled trials with tolvaptan, outwards the positive effect involving the physical component, the mental component pointed out a significant trend [19, 69, 72, 74]. The SALT-2 ("Study of Ascending Levels of Tolvaptan in Hyponatremia") extensive randomized placebocontrolled trial was exhibited in a preliminary form. 243 hyponatraemic patients were permitted to receive 15 to $60 \mathrm{mg} /$ day tolvaptan in a gradual manner for a 30-day period. Patients receiving tolvaptan compared to placebo were yield increased serum sodium levels as well as results of the lixivaptan trials $[68,69,72,74]$. But, $25 \%$ of patients discard the study, and resistance (defined as the nonfulfillment of an enhancement in the serum sodium by $\geq 5 \mathrm{mEq} / \mathrm{L}$ ) materialised for $37 \%$ of patients with congestive heart failure, $17 \%$ with cirrhosis, and $11 \%$ of patients with associated SIADH, respectively [67, 74].

Otsuka (Otsuka Pharmaceutical, Osaka, Japan), the pharmaceutical company that manufactures tolvaptan, 
recommends the use of this drug in a dose range of 15 to $30 \mathrm{mg}$ once daily p.o. for $\mathrm{hNa}$ [75]. In the United States, the price for a tablet is approximately USD 150. In Germany, a tablet's price (15 or $30 \mathrm{mg}$ / tablet alike) is at the moment Euro 105, approximatively equivalent to USD 115 [76]. In this regard, a vaptan treatment for a month - if that were evermore to be administered to a patient - rises to approximatively Euro 4500 in Europe or USD 8300 in the United States [76]. These high prices are pertinent to be spent in the hypervolemic hNa. In euvolemic $\mathrm{hNa}$, the vaptans treatments costs are similar to be dropped, because it is noticed an outstanding responsiveness to vaptan. The calculations exceed these numbers in the case of chronic haemodialysis for a month. In the same class of drugs, the therapy expenditure is different, meaning tolvaptan therapy is even less expensive than conivaptan in Europe [64-66, 76]. Surveilling the literature data, we cannot find any published prospective study that should justify such costs in the benefit of the patient and also, further, to the healthcare system. Considering that the largest mass of hyponatraemic patients are clinically oligosymptomatic or asymptomatic, the raised question is that urea has more sense for treating chronic hNa? In this regard, a comparative study involving urea and vaptan therapy, enrolling patients with mild hNa, would be more designated to exhibit the quality-oflife features, the efficacy, and the cost of both treatments [76].

Table III

Clinical trials with vaptans

\begin{tabular}{|c|c|c|c|c|c|c|}
\hline $\begin{array}{c}\text { Clinical trial or } \\
\text { reference }\end{array}$ & Study design & $\begin{array}{c}\text { Patient } \\
\text { population }\end{array}$ & Treatment arms & Goal & Results & $\begin{array}{l}\text { Adverse } \\
\text { reactions }\end{array}$ \\
\hline $\begin{array}{l}\text { Hypervolemic } \\
\text { or euvolemic } \\
\text { hNa }[3,37,77, \\
78]\end{array}$ & $\begin{array}{l}\text { Prospective, } \\
\text { multicentre, } \\
\text { open-label } \\
\text { RCCT }\end{array}$ & $\begin{array}{l}28 \text { Hospitalized } \\
\text { patients }\left(\mathrm{s}\left[\mathrm{Na}^{+}\right] \leq\right. \\
135 \mathrm{mEq} / \mathrm{L} \geq 2 \\
\text { consecutive days })+ \\
\mathrm{HF}, \text { liver cirrhosis, } \\
\text { SIADH, and } \\
\text { normovolemia or } \\
\text { fluid overcharge }\end{array}$ & $\begin{array}{l}2: 1 \text { ratio } \\
\text { Oral Tolvaptan }(\mathrm{OPC}-41061) \\
\text { alone }(n=17) \text { - starting dose } 10 \\
\mathrm{mg} / \text { day, raised to } 60 \mathrm{mg} / \text { day } \\
\text { Fluid restriction }(n=11)(1200 \\
\mathrm{mL} / \text { day })+ \text { Placebo, individualized } \\
\left.\text { to obtain normalized s[Na }{ }^{+}\right] \\
\text {For } 12 \text { days or until the inpatient } \\
\text { stay, whichever comes first }\end{array}$ & $\begin{array}{l}\text { Normalization of } \\
\mathrm{s}\left[\mathrm{Na}^{+}\right] \\
\text {achieved with } \\
\text { tolvaptan }\end{array}$ & $\begin{array}{l}\text { Significantly higher rate of } \\
\text { subjects obtained normalization } \\
\text { of } \mathrm{s}\left[\mathrm{Na}^{+}\right] \text {in the tolvaptan group } \\
(\mathrm{p}=0.007) \text { compared with the } \\
\text { fluid-restriction group }(\mathrm{p}=0.049)\end{array}$ & $\begin{array}{l}\text { No adverse events } \\
\text { requiring } \\
\text { discontinuation }\end{array}$ \\
\hline $\begin{array}{l}\text { SALT-1 and } \\
\text { SALT-2 }[3,37, \\
72,78,79]\end{array}$ & $\begin{array}{l}\text { Multicentre, } \\
\text { double-blind, } \\
\text { placebo } \\
\text { controlled } \\
\text { RCCT }\end{array}$ & \begin{tabular}{|l|}
448 Patients aged \\
$\geq 18$ years with \\
mild $(\mathrm{s}[\mathrm{Na}+]=$ \\
$130-135 \mathrm{mEq} / \mathrm{L})$ \\
or pronounced \\
hNa subordinate to \\
chronic $\mathrm{HF}$, cirrhosis, \\
or SIADH
\end{tabular} & $\begin{array}{l}\text { Oral Tolvaptan }(n=225) \\
\text { starting dose } 15 \mathrm{mg} / \text { day, raised to } \\
\text { a highest dose of } 60 \mathrm{mg} / \text { day, } \\
\text { according to } \mathrm{s}\left[\mathrm{Na}^{+}\right] \\
\text {Placebo }(n=223) \\
\text { For } 30 \text { days }\end{array}$ & \begin{tabular}{|l|} 
Change from \\
baseline and in the \\
daily average \\
AUC for $\mathrm{s}\left[\mathrm{Na}^{+}\right]$to \\
days 4 and 30
\end{tabular} & & \multirow{3}{*}{$\begin{array}{l}\text { Placebo and } \\
\text { Tolvaptan: } \\
\text { thirst, dry mouth, } \\
\text { increased } \\
\text { urination, ascites, } \\
\text { constipation, } \\
\text { diarrhoea, nausea, } \\
\text { vomiting, } \\
\text { weakness, fatigue, } \\
\text { peripheral } \\
\text { oedema, } \\
\text { weakness, } \\
\text { urinary tract } \\
\text { infections, hyper- } \\
\text { glycaemia, hyper- } \\
\text { kalaemia, } \\
\text { dizziness, } \\
\text { headache }\end{array}$} \\
\hline SALT-1 & & 205 Patients & $\begin{array}{l}\text { Oral Tolvaptan }(n=102) \\
\text { Placebo }(n=103)\end{array}$ & & $\begin{array}{l}\text { Day } 4: 3.62(2.68) \text { with } \\
\text { tolvaptan }(\mathrm{n}=95) \text { and } 0.25 \\
(2.08) \mathrm{mEq} / \mathrm{L} \text { with placebo }(\mathrm{n}= \\
89),(\mathrm{p}<0.001) . \\
\text { Day } 30: 6.22(4.10) \text { with } \\
\text { tolvaptan and } 1.66(3.59) \\
\mathrm{mmol} / \mathrm{L}(\mathrm{n}=95) \text { with placebo } \\
(\mathrm{n}=89)(\mathrm{p}<0.001)\end{array}$ & \\
\hline SALT-2 & & 243 Patients & $\begin{array}{l}\text { Oral Tolvaptan }(n=123) \\
\text { Placebo }(n=120)\end{array}$ & & $\begin{array}{l}\text { Day } 4: 4.33(2.87) \text { with } \\
\text { tolvaptan and } 0.42(2.56) \\
\mathrm{mEq} / \mathrm{L}(\mathrm{n}=118) \text { with placebo } \\
(\mathrm{n}=114)(\mathrm{p}<0.001) . \\
\text { Day } 30: 6.20(3.92) \text { with } \\
\text { tolvaptan and } 1.84(3.83) \\
\mathrm{mEq} / \mathrm{L}(\mathrm{n}=118) \text { with placebo } \\
(\mathrm{n}=114)(\mathrm{p}<0.001) .\end{array}$ & \\
\hline $\begin{array}{l}\text { EVEREST } \\
\text { (clinical status } \\
\text { trials) }[37, \mathbf{7 0 ,} \\
\mathbf{7 8}]\end{array}$ & $\begin{array}{l}\text { Prospective, } \\
\text { multicentred, } \\
\text { double-blind, } \\
\text { placebo- } \\
\text { RCCT }\end{array}$ & \begin{tabular}{|l|}
4118 Hospitalized \\
patients aged $\geq 18$ \\
years with an $\mathrm{EF} \leq$ \\
$40 \%+$ worsening \\
$\mathrm{HF}$ symptoms/ \\
minimal exertion + \\
$\geq 2$ signs of \\
congestion \\
(dyspnoea, \\
peripheral \\
oedema)
\end{tabular} & $\begin{array}{l}\text { Oral Tolvaptan }(n=2063) \\
30 \mathrm{mg} / \text { day } \\
\text { Placebo }(n=2055) \\
\text { initiated in no more than } 48 \text { hours } \\
\text { of the admittance, for } \geq 7 \\
\text { inpatient days or until discharge }\end{array}$ & \begin{tabular}{|l|} 
Mean (SD) \\
changes in global \\
health status and \\
body weight at day \\
7 or discharge if \\
earlier; \\
improvement in \\
dyspnoea and \\
peripheral oedema \\
and global clinical \\
status
\end{tabular} & 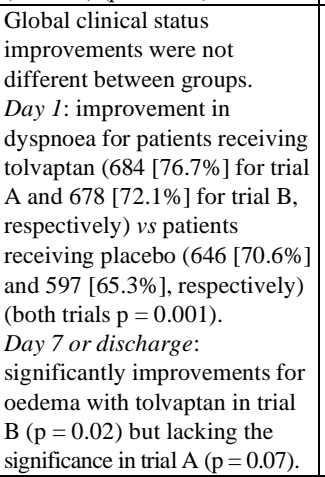 & \\
\hline TRIAL A & & 2042 Patients & $\begin{array}{l}\text { Tolvaptan }(n=1015) \\
\text { Placebo }(n=1027)\end{array}$ & & $\begin{array}{l}\text { Higher improvement with } \\
\text { tolvaptan } v \text { s placebo (mean } \\
[\mathrm{SD}], 1.06[0.43] \text { vs } 0.99[0.44]) \\
\text { Day } 1: \text { mean }(\mathrm{SD}) \text { body weight } \\
\text { decrease was major with } \\
\text { tolvaptan }(1.71[1.80] \text { vs } 0.99 \\
[1.83] \mathrm{kg} ; \mathrm{p}=0.001) \text {. }\end{array}$ & $\begin{array}{l}\text { Thirst, dry mouth, } \\
\text { constipation, } \\
\text { hypernatremia, } \\
\text { pollakiuria, and } \\
\text { polyuria }\end{array}$ \\
\hline
\end{tabular}


FARMACIA, 2020, Vol. 68, 3

\begin{tabular}{|c|c|c|c|c|c|c|}
\hline $\begin{array}{c}\text { Clinical trial or } \\
\text { reference }\end{array}$ & \begin{tabular}{|l|} 
Study design \\
\end{tabular} & $\begin{array}{c}\text { Patient } \\
\text { population }\end{array}$ & Treatment arms & Goal & Results & $\begin{array}{l}\text { Adverse } \\
\text { reactions }\end{array}$ \\
\hline & & & & & $\begin{array}{l}\text { Day } 7 \text { or discharge: }(3.35[3.27] \\
\text { vs } 2.73[3.34] \mathrm{kg} ; \mathrm{p}=0.001)\end{array}$ & \\
\hline TRIAL B & & 2076 Patients & $\begin{array}{l}\text { Tolvaptan }(n=1048) \\
\text { Placebo }(n=1028)\end{array}$ & & $\begin{array}{l}\text { Major improvement with } \\
\text { tolvaptan } \text { vs placebo }(1.07 \\
[0.42] \text { vs } 0.97 \text { [0.43]; } \mathrm{p}=0.001) \\
\text { Day } 1: \text { mean }(\mathrm{SD}) \text { body weight } \\
\text { decrease was higher with } \\
\text { tolvaptan }(1.82[2.01] \text { vs } 0.95 \\
[1.85] \mathrm{kg} ; \mathrm{p}=0.001) . \\
\text { Day } 7 \text { or discharge: }(3.77 \\
{[3.59] \text { vs } 2.79 \text { [3.46] kg; } \mathrm{p}=} \\
0.001) .\end{array}$ & $\begin{array}{l}\text { Thirst, dry mouth, } \\
\text { constipation, } \\
\text { polyuria, } \\
\text { pollakiuria, } \\
\text { and } \\
\text { hypernatremia. }\end{array}$ \\
\hline \begin{tabular}{|l|} 
Vasopressin \\
blockade with \\
tolvaptan in \\
chronic heart \\
failure HF [4, \\
37, 76, 78, 80] \\
\end{tabular} & \begin{tabular}{|l|} 
Multicentre, \\
double blind, \\
placebo- \\
RCCT
\end{tabular} & \begin{tabular}{|l|}
254 Patients aged \\
$\geq 18$ years + HF \\
symptoms for $\geq 30$ \\
days (irrespective \\
of EF) + treatment \\
with a fixed dose \\
of oral FUR for $\geq$ \\
7 days before \\
enrolment for \\
signs of volume \\
overload \\
\end{tabular} & $\begin{array}{l}\text { Oral Tolvaptan }(\text { OPC-41061) } \\
30 \mathrm{mg} / \text { day }(n=64) \\
45 \mathrm{mg} / \text { day }(n=62) \\
60 \mathrm{mg} / \text { day }(n=61) \\
\text { Placebo }(n=62) \text { one dose daily } \\
25 \text { days }\end{array}$ & $\begin{array}{l}\text { Change from } \\
\text { baseline in the } \\
\text { body weight }\end{array}$ & $\begin{array}{l}\text { Reduction of the body weight } \\
\text { by } 0.84 \mathrm{~kg} \text { in the tolvaptan } \\
\text { group and improved } \mathrm{hNa}(\mathrm{p}< \\
0.001) v s \text { placebo between } \\
\text { doses }\end{array}$ & $\begin{array}{l}\text { Thirst, polyuria, } \\
\text { dry mouth, } \\
\text { dizziness, } \\
\text { weakness }\end{array}$ \\
\hline \multirow{4}{*}{\begin{tabular}{|l} 
Tolvaptan in \\
patients \\
hospitalized \\
with worsening \\
heart failure \\
{$[76,78,81,82]$}
\end{tabular}} & \multirow{4}{*}{\begin{tabular}{|l|} 
Multicentre, \\
double-blind, \\
placebo-RCT \\
parallel- \\
group, dose- \\
ranging trial, \\
phase 2
\end{tabular}} & \multirow{4}{*}{$\begin{array}{l}319 \text { Hospitalized } \\
\text { patients aged } \geq 18 \\
\text { years with } \\
\text { decompensated } \\
\text { systolic HF (EF < } \\
40 \%), \text { rales, or } \\
\text { peripheral oedema } \\
\text { after failure of } \\
\text { initial in-hospital } \\
\text { treatment of HF } \\
\end{array}$} & \multirow{4}{*}{$\begin{array}{l}\text { Oral Tolvaptan } \\
30 \mathrm{mg} / \text { day }(n=78) \\
60 \mathrm{mg} / \text { day }(n=84) \\
90 \mathrm{mg} / \text { day }(n=76) \\
\text { Placebo }(n=79) \\
\text { Within } 96 \text { hours of admission, for } \\
60 \text { days }\end{array}$} & \multicolumn{2}{|c|}{ Part 1 (inpatient, $\leq 10$ days) } & \multirow{4}{*}{$\begin{array}{l}\text { Dry mouth, thirst, } \\
\text { nausea, dizziness, } \\
\text { and hypotension }\end{array}$} \\
\hline & & & & \begin{tabular}{|l|} 
Mean change in \\
body weight at 24 \\
hours after the first \\
dose taken. \\
\end{tabular} & $\begin{array}{l}\text { In the first } 24 \mathrm{~h} \text {, body weight } \\
\text { decreased by } 1.4 \mathrm{~kg} v s \text { placebo. }\end{array}$ & \\
\hline & & & & \multicolumn{2}{|c|}{ Part 2 (outpatient, 60 days) } & \\
\hline & & & & \begin{tabular}{|l} 
Proportion with \\
worsening HF (at \\
60 days after \\
randomization). \\
\end{tabular} & $\begin{array}{l}\text { No significant difference in } \\
\text { worsening heart failure. }\end{array}$ & \\
\hline $\begin{array}{l}\text { Udelson } \text { et al. } \\
(2008)[3,37 \\
78,83]\end{array}$ & \begin{tabular}{|l|} 
Multicentre, \\
double-blind, \\
placebo- \\
RCCT
\end{tabular} & \begin{tabular}{|l|}
181 Patients aged \\
$\geq 18$ years with an \\
EF $<40 \%$ and \\
NYHA functional \\
class III - IV. HF \\
treatment for $\geq 1$ \\
month and PCWP \\
$>18 \mathrm{~mm}$ Hg on 2 \\
readings $\geq 10$ \\
minutes apart $2 \mathrm{hrs}$ \\
before study drug \\
administration \\
\end{tabular} & $\begin{array}{l}\text { Oral tolvaptan (fixed dose) } \\
15 \mathrm{mg} / \text { day } \\
30 \mathrm{mg} / \text { day } \\
60 \mathrm{mg} / \text { day } \\
\text { Placebo }\end{array}$ & $\begin{array}{l}\text { Mean (SD) change } \\
\text { from baseline in } \\
\text { PCWP } 3-8 \text { hrs } \\
\text { after treatment } \\
\text { administration }\end{array}$ & $\begin{array}{l}-6.38(4.12) \mathrm{mm} \mathrm{Hg} \text { with } 15 \\
\mathrm{mg} / \mathrm{day}(\mathrm{p}<0.01) \\
-5.67(4.58) \mathrm{mm} \mathrm{Hg} \text { with } 30 \\
\mathrm{mg} / \mathrm{day}(\mathrm{p}<0.05) \\
-5.71(4.35) \mathrm{mm} \mathrm{Hg} \text { with } 60 \\
\mathrm{mg} / \mathrm{day}(\mathrm{p}<0.05) \\
-4.16(4.57) \mathrm{mm} \mathrm{Hg} \text { with } \\
\text { placebo } \\
(\mathrm{p}=\text { NS between doses })\end{array}$ & \begin{tabular}{|l} 
Patient-reported \\
adverse events \\
appeared in: \\
$45.5 \%$ with 15 \\
mg/day tolvaptan, \\
$44.2 \%$ with 30 \\
mg/day, \\
$54.3 \%$, with 60 \\
mg/ day, $33.3 \%$ \\
with placebo, \\
respectively
\end{tabular} \\
\hline Ghali et al. [84] & \begin{tabular}{|l|} 
Double-blind, \\
placebo- \\
controlled, \\
multicentre \\
study
\end{tabular} & \begin{tabular}{|l|}
51 hospitalized \\
euvolemic and \\
hyponatraemic \\
patients aged $>18$ \\
years with s[Na+] \\
$\leq 130 \mathrm{mEq} / \mathrm{L}$, \\
serum osmolality \\
$<290 \mathrm{mOsm} / \mathrm{kg}$ \\
$\mathrm{H}_{2} 0$ secondary to \\
malignancy, CHF \\
or idiopathic \\
\end{tabular} & $\begin{array}{l}\text { Oral conivaptan } \\
\text { initial dose } \mathbf{4 0 ~} \mathbf{~ m g / d a y}(n=24) \\
\text { initial dose } 80 \mathrm{mg} / \text { day in two } \\
\text { divided doses }(n=27) \\
\text { Placebo }(n=23) \\
5 \text { days } \\
\text { Fluid restriction } 2 \text { L/day }\end{array}$ & \begin{tabular}{|l} 
Change from \\
baseline for $\mathrm{s}\left[\mathrm{Na}^{+}\right]$ \\
and AUC to day 5
\end{tabular} & $\begin{array}{l}\text { Both doses showed significant } \\
\text { improvements over placebo } \\
2.0 \text {-fold: higher for the } 40 \mathrm{mg} / \\
\text { day dose }(\mathrm{p}=0.03) \text { and } 2.5- \\
\text { fold higher for the } 80 \mathrm{mg} / \text { day } \\
\text { dose }(\mathrm{p}<0.001)\end{array}$ & $\begin{array}{l}\text { Headache, nausea, } \\
\text { constipation, and } \\
\text { postural hypo- } \\
\text { tension }\end{array}$ \\
\hline $\begin{array}{l}\text { BALANCE } \\
\text { study [85] }\end{array}$ & \begin{tabular}{|l|} 
Double-blind, \\
placebo- \\
RCCT, \\
phase 3
\end{tabular} & \begin{tabular}{|l|}
650 hospitalized \\
patients aged $>18$ \\
years with \\
worsening heart \\
failure congestion \\
and $\mathrm{s}\left[\mathrm{Na}^{+}\right] \leq 135$ \\
$\mathrm{mEq} / \mathrm{L}$
\end{tabular} & $\begin{array}{l}1: 1 \text { ratio } \\
\text { Oral lixivaptan }(n=325) \\
\text { starting dose } 50 \mathrm{mg} / \text { daily up to } \\
100 \mathrm{mg} \text { twice daily based on } \\
\mathrm{s}\left[\mathrm{Na}^{+}\right] \text {and volume status } \\
\text { Fluid restriction } \\
\text { Placebo }(n=325) \\
60 \text { days with a } 30 \text { days follow-up }\end{array}$ & \begin{tabular}{|l|} 
Change from \\
baseline in $\mathrm{s}\left[\mathrm{Na}^{+}\right]$ \\
at day 7
\end{tabular} & $\begin{array}{l}\text { Increased } \mathrm{s}\left[\mathrm{Na}^{+}\right] \text {and reduced } \\
\text { body weight, without renal } \\
\text { dysfunction or hypokalaemia }\end{array}$ & \\
\hline \multirow[t]{2}{*}{$\begin{array}{l}\text { Soupart et al. } \\
\text { [86] }\end{array}$} & \begin{tabular}{|l|} 
Double-blind \\
$\mathbf{1}^{\text {st }}$ phase, \\
multicentre, \\
RCCT
\end{tabular} & $\begin{array}{l}34 \text { patients aged }> \\
62 \text { years with } \mathrm{hNa} \\
\text { consecutive } \\
\text { SIADH }\end{array}$ & $\begin{array}{l}\text { Oral Satavaptan } \\
25 \mathrm{mg} / \text { day }(n=14) \\
50 \mathrm{mg} / \text { day }(n=12) \\
\text { Placebo }(n=8) \\
7 \text { to } 30 \text { days } \\
\text { Fluid restriction }<1.5 \mathrm{~L} / \text { day }\end{array}$ & \begin{tabular}{|l|} 
Change from \\
baseline in $\mathrm{s}\left[\mathrm{Na}^{+}\right]$
\end{tabular} & $\begin{array}{l}\text { Increase of } \mathrm{s}\left[\mathrm{Na}^{+}\right] \text {following } \\
\text { satavaptan } 25 \mathrm{mg} / \text { day }(\mathrm{p}< \\
0.01) \text { and } 50 \mathrm{mg} / \text { day }(\mathrm{p}< \\
0.001) \text { vs placebo. }\end{array}$ & \\
\hline & $\begin{array}{l}\text { Open label } \\
2^{\text {nd }} \text { phase, } \\
\text { multicentre, } \\
\text { CCT }\end{array}$ & $\begin{array}{l}22 \text { patients with } \\
\text { hNa consecutive } \\
\text { SIADH }\end{array}$ & $\begin{array}{l}\text { Oral Satavaptan }(n=22) \\
\text { increasing doses } 12.5,25,50 \\
\mathrm{mg} / \text { day } \\
12 \text { months } \\
\text { Fluid restriction }<1.5 \mathrm{~L} / \text { day } \\
\end{array}$ & $\begin{array}{l}\text { Change from } \\
\text { baseline in } \mathrm{s}\left[\mathrm{Na}^{+}\right]\end{array}$ & $\begin{array}{l}15 \text { of } 18 \text { enrolled subjects } \\
\text { fulfilled } 6 \text { months and } 10 \\
\text { fulfilled } 12 \text { months of } \\
\text { treatment. }\end{array}$ & $\begin{array}{l}\text { Urinary tract } \\
\text { infection, vomiting, } \\
\text { pruritus, stomatitis, } \\
\text { vasculitis, cryo- } \\
\text { globulinemia } \\
\end{array}$ \\
\hline $\begin{array}{l}\text { Gines P et al. } \\
{[87]}\end{array}$ & $\begin{array}{l}\text { Double-blind, } \\
\text { multicentric, } \\
\text { RCCT }\end{array}$ & \begin{tabular}{|l|}
110 hyponatraemic \\
patients with \\
cirrhosis with \\
ascites
\end{tabular} & \begin{tabular}{|l} 
Oral satavaptan \\
$5 \mathrm{mg} /$ day $(n=28)$ \\
$12.5 \mathrm{mg} / \mathrm{day}(n=26)$ \\
$25 \mathrm{mg} /$ day $(n=28)$ \\
\end{tabular} & \begin{tabular}{|l|} 
Changes from \\
baseline in $\mathrm{s}[\mathrm{Na}+]$ \\
to day 5 and in \\
body weight (day 1$)$
\end{tabular} & $\begin{array}{l}\text { Improvements in } \mathrm{s}\left[\mathrm{Na}^{+}\right](\mathrm{p}< \\
0.01 \text { for all groups versus } \\
\text { placebo). } \\
\text { Improved management of }\end{array}$ & Thirst \\
\hline
\end{tabular}


FARMACIA, 2020, Vol. 68, 3

\begin{tabular}{|c|c|c|c|c|c|c|}
\hline \begin{tabular}{|c|} 
Clinical trial or \\
reference
\end{tabular} & Study design & $\begin{array}{c}\text { Patient } \\
\text { population }\end{array}$ & "Treatment arms & "Goal & Results & $\begin{array}{l}\text { Adverse } \\
\text { reactions }\end{array}$ \\
\hline & & & $\begin{array}{l}\text { Placebo }(n=28) \\
\text { Fluid restriction }<1.5 \mathrm{~L} / \text { day } \\
\text { Spironolactone } 100 \mathrm{mg} / \text { day } \\
\text { For } 14 \text { days }\end{array}$ & $\begin{array}{l}\text { to the end of } \\
\text { treatment (day 14) }\end{array}$ & $\begin{array}{l}\text { ascites, as prevailed by a } \\
\text { reduction in body weight ( } \mathrm{p}= \\
0.05 \text { for a dose-effect } \\
\text { relationship overall). }\end{array}$ & \\
\hline \begin{tabular}{|l|} 
Yamagouchi $e t$ \\
al. $[88]$
\end{tabular} & $\begin{array}{l}\text { Multicentred, } \\
\text { open-labelled } \\
\text { CT }\end{array}$ & $\begin{array}{l}16 \text { patients aged }> \\
48 \text { years with } \\
\text { malignancies }\end{array}$ & $\begin{array}{l}\text { Oral Mozavaptan } \\
30 \mathrm{mg} / \text { day for } 7 \text { days or for } 3 \\
\text { days when it was allowed } \\
\text { Fluid restriction was permitted } \\
\text { throughout the study period only } \\
\text { For participants in whom it had } \\
\text { already begun }\end{array}$ & $\begin{array}{l}\text { Change from } \\
\text { baseline in } \mathrm{s}\left[\mathrm{Na}^{+}\right]\end{array}$ & $\begin{array}{l}\mathrm{s}\left[\mathrm{Na}^{+}\right](\text {mean }+\mathrm{SD}) \\
\text { significantly } \\
(\mathrm{p}=0.002) \text { increased from } \\
122.8+6.7 \text { to } 133.3+8.3 \\
\mathrm{mEq} / \mathrm{L}\end{array}$ & $\begin{array}{l}\text { Dry mouth, } \\
\text { increased blood } \\
\mathrm{K}^{+} \text {and } \mathrm{Ca}^{2+} \text { levels }\end{array}$ \\
\hline
\end{tabular}

RCCT - randomized controlled clinical trial; $\mathrm{s}\left[\mathrm{Na}^{+}\right]$- serum sodium concentration; AUC - area under curve; FUR - furosemide; EF - ejection fraction; HF - heart fraction; NYHA - New York Heart Association; PCWP - pulmonary capillary wedge pressure; NS - not-significant

\section{Are vaptans safe for elders?}

The safety profile is the first and foremost preoccupation in the treatment of older patients when new agents are developed. As the preclinical data disclose, these drugs are potent aquaretic agents, e.g., in the tolvaptan studies [82], the observed diuresis exceeded more than 4 litters per day [70]. However, the incidence of adverse effects occurrence after administering tolvaptan medication was alike to that noticed within the placebo group in the SALT trials [72]. In the first month of therapy, ordinary adverse effects comprised thirst $(14 \%)$, dry mouth $(13 \%)$, weakness $(9 \%)$, constipation $(9 \%)$ and nausea (8\%) [82]. In the EVEREST study [70], with a median 9.9 months of treatment, tolvaptan evidenced a good safety profile, although this has to be rendered with precaution as only $10 \%$ of participants were suffering of $\mathrm{hNa}$. In the framework of an openlabel extension of the SATWATER trial [72], 6 out of 111 subjects in the study discontinued the treatment because of the drug adverse reactions [82]. Short follow-up was reported in the subsequent studies $[50,52,82]$. However, it is raised the uncertainty that tolvaptan would be as properly accepted in elderly patients, especially taking into account the dehydrated, misdiagnosed with SIADH patients [82] linked to the potential for inappropriate prescription. The mean ages of the clinical trials participants were solely 60 years in SALT-1, 62 years in SALT-2 and 65 years in SALTWATER [67, 69, 82], although the oldest volunteer was 100 years old in SALT trials. The tolerability regarding the age group is not very clearly explained and needs further assessment in randomised controlled clinical trials with a large number of older participants. On a balance, at the present, vaptans are the solution where uncomplicated and low-priced resources collapsed. But, in very elderly patients, the reliance for their use might be undervalued [74], because in this type of age group, $\mathrm{hNa}$ is rather ordinary [82]. The postural balance and cognition refinements should be put in opposite with a younger population. The economic burden of uncorrected $\mathrm{hNa}$ on relapses [75, 84, 89] and cognitive impairment [76] embrace a large number, and the life expectation of hyponatraemic elders could provide an expectation of a potentially life-long treatment more sustainable to healthcare funders [82]. Overall, vaptan therapy rise a question mark regarding the safe and costeffective sections.

\section{Conclusions}

The capacity of vaptans to treat hyponatremia is still blurred. Their employment in patients with hypovolemic $\mathrm{hNa}$, symptomatic $\mathrm{hNa}$, and especially with damaged liver is labelled with a big question mark. Not so effective in cirrhosis, they also lead to a fortunate aquaresis in patients with chronic heart failure and the outliving was not astonishing. But, nevertheless, vaptans are a key solution in the management of SIADH even with an underneath starting dose of $7.5 \mathrm{mg}$. As emphasized in preliminary studies, the potential beneficial employment of vasopressin-receptor antagonists is found for treating Raynaud's syndrome, Meniere's disease, dysmenorrhoea, ACTH-independent macronodular adrenal hyperplasia, and depressive disorders. In the elderly population, subtracted serum sodium concentration is an ordinary condition in view of the extension factors leading to increased $\mathrm{ADH}$ and the perpetual prescribed medication associated with $\mathrm{hNa}$, especially antidepressants, antipsychotics, or antiepileptics. Both in outpatient and inpatient settings, the assessment, and the treatment of $\mathrm{hNa}$ in the elderly patients arise for any clinician many challenges. They should brief in themselves with the correct way of using vaptans, because recommending vaptans for treating $\mathrm{hNa}$ is the future goal for this disease, because of the additionally gathered experience with this class of agents.

\section{Conflict of interest}

The authors declare no conflict of interest.

\section{References}

1. Chawla A, Sterns RH, Nigwekar SU, Cappuccio JD, Mortality and serum sodium: do patients die from or with hyponatremia?. Clin J Am Soc Nephrol., 2011; 6(5): 960-965.

2. Adrogué $\mathrm{HJ}$, Consequences of Inadequate Management of Hyponatremia. Am J Nephrol., 2005; 25: 240-249.

3. Filippatos TD, Makri A, Elisaf MS, Liamis G, Hyponatremia in the elderly: challenges and solutions. Clin Interv Aging., 2017; 12: 1957-1965. 
FARMACIA, 2020, Vol. 68, 3

4. Cortés MM, Muñoz PG, Hyponatremia and Psychotropic Drugs, Chapter 2 in "Fluid and electrolyte disorders". Book edited by Usman Mahmood, InTech, London, 2019, DOI 10.5772/intechopen.72967.

5. Spasovski G, Vanholder R, Allolio B, Annane D, Ball S, Bichet D, Decaux G, Fenske W, Hoorn EJ, Ichai C, Joannidis M, Soupart A, Zietse R, Haller M, van der Veer S, van Biesen W, Nagler E, Hyponatraemia Guideline Development Group. Clinical practice guideline on diagnosis and treatment of hyponatraemia [published correction appears in Nephrol Dial Transplant. 2014; 40(6):924]. Nephrol Dial Transplant., 2014; 29(2): i1-i39.

6. Sahay M, Sahay R, Hyponatremia: A practical approach. Indian J Endocrinol Metab., 2014; 18(6): 760-771.

7. Feixia Z, Xiuyun Y, Xulai S, Zhongdong L, Zuqin Y, Hyponatremia in Children With Bacterial Meningitis. Front Neurol., 2019; 10(421): 1-8.

8. Vu T, Wong R, Hamblin PS, Zajac J, Grossmann M, Patients presenting with severe hypotonic hyponatremia: etiological factors, assessment, and outcomes. Hosp Pract., 2009; 37(1): 128-136.

9. Cluitmans FH, Meinders AE, Management of severe hyponatremia: rapid or slow correction?. Am J Med., 1990; 88(2): 161-166.

10. Rafat C, Schortgen F, Gaudry S, Bertrand F, MiguelMontanes R, Labbé V, Ricard JD, Hajage D, Use of desmopressin acetate in severe hyponatremia in the intensive care unit. Clin J Am Soc Nephrol., 2014; 9(2): 229-237.

11. Sood L, Sterns RH, Hix JK, Silver SM, Chen L, Hypertonic saline and desmopressin: a simple strategy for safe correction of severe hyponatremia. Am J Kidney Dis., 2013; 61(4): 571-578.

12. Hannon MJ, Thompson CJ, The syndrome of inappropriate antidiuretic hormone: prevalence, causes and consequences. Eur J Endocrinol., 2010; 162(1): S5-S12.

13. Bartter FC, Schwartz WB, The syndrome of inappropriate secretion of antidiuretic hormone. Am J Med., 1967; 42(5): 790-806.

14. Stelmach E, Hołownia O, Słotwiński M, Gerhant A, Olajossy M, Hiponatremia in the practice of a psychiatrist. Part 1: SIADH syndrome and druginduced hyponatremia. Curr Probl Psychiatry, 2017; 18(2): 120-137.

15. Gheldiu AM, Vlase L, Popa A, Muntean D, Bocşan C, Buzoianu A, Neag M, Leucuța D, Briciu C, Assessment of the effects of steady-state bupropion on the pharmacokinetic profile of zolpidem in healthy volunteers. Farmacia, 2019; 67(3): 430-436.

16. Hillier TA, Abbott RD, Barrett EJ, Hyponatremia: evaluating the correction factor for hyperglycemia. Am J Med., 1999; 106(4): 399-403.

17. Strange K, Regulation of solute and water balance and cell volume in the central nervous system. $J A m$ Soc Nephrol., 1992; 3(1): 12-27.

18. Ellison DH, Berl T, Clinical practice. The syndrome of inappropriate antidiuresis. $N$ Engl J Med., 2007; 356(20): 2064-2072

19. Verbalis JG, Goldsmith SR, Greenberg A, Korzelius C, Schrier RW, Sterns RH, Thompson CJ, Diagnosis, evaluation, and treatment of hyponatremia: expert panel recommendations. Am J Med., 2013; 126(10): S1-S42.
20. Klinke JA, Shapira SC, Akbari E, Holmes DT, Quetiapine associated cholestasis causing lipoprotein- $\mathrm{X}$ and pseudohyponatraemia. J Clin Pathol., 2010; 63(8): 741-743.

21. Tanneau RS, Henry A, Rouhart F, Bourbigot B, Garo B, Mocquard Y, Goas JY, High incidence of neurologic complications following rapid correction of severe hyponatremia in polydipsic patients. $J$ Clin Psychiatry, 1994; 55(8): 349-354.

22. Bähr V, Franzen N, Oelkers W, Pfeiffer A, Diederich $\mathrm{S}$, Effect of exogenous glucocorticoid on osmotically stimulated antidiuretic hormone secretion and on water reabsorption in man. Eur J Endocrinol., 2006; 155(6): 845-848.

23. Rondon H, Badireddy M, Hyponatremia. 2020, Stat Pearls Publishing, Treasure Island (FL).

24. Adrogue HJ, Madias NE, The challenge of hyponatremia. J Am Soc Nephrol., 2012; 23(7): 1140-1148.

25. Berl T, An elderly patient with chronic hyponatremia. Clin J Am Soc Nephrol., 2013; 8: 469-475.

26. Upadhyay A, Jaber BL, Madias NE, Incidence and prevalence of hyponatremia. Am J Med., 2006; 119(7): S30-S35.

27. Miller M, Morley JE, Rubenstein LZ, Hyponatremia in a nursing home population. $J$ Am Geriatr Soc., 1995; 43(12): 1410-1413.

28. Frenkel WN, van den Born BJ, van Munster BC, Korevaar JC, Levi M, de Rooij SE, The association between serum sodium levels at time of admission and mortality and morbidity in acutely admitted elderly patients: a prospective cohort study. $J \mathrm{Am}$ Geriatr Soc., 2010; 58(11): 2227-2228.

29. Caird FI, Andrews GR, Kennedy RD, Effect of posture on blood pressure in the elderly. Br Heart J., 1973; 35: 527-530.

30. DeVita MV, Gardenswartz MH, Konecky A, Zabetakis $\mathrm{PM}$, Incidence and etiology of hyponatremia in an intensive care unit. Clin Nephrol., 1990; 34(4): 163-166.

31. Funk GC, Lindner G, Druml W, Metnitz B, Schwarz $\mathrm{C}$, Bauer P, Metnitz PGH, Incidence and prognosis of dysnatremias present on ICU admission. Intensive Care Med., 2010; 36(2): 304-311.

32. Raju B, Rishab A, Vikram K, Vaibhav T, Sharat T, Kopal G, Santosh K, Shreyas A, Epidemiology of hyponatraemia among elderly patients with lower respiratory tract infection. BJM., 2020; 31: 13-17.

33. Hawkins RC, Age and gender as risk factors for hyponatremia and hypernatremia. Clin Chim Acta, 2003; 337: 169-172.

34. Mohan S, Gu S, Parikh A, Radhakrishnan J, Prevalence of hyponatremia and association with mortality: results from NHANES. Am J Med., 2013; 126(12): 1127-1137.

35. Sandeep Grover, Anish Shouan, Aseem Mehra, Subho Chakrabarti, Ajit Avasthi, Antidepressantassociated hyponatremia among the elderly: A retrospective study. J Geriatr Ment Health, 2018; 5(2): 115-120.

36. Adrogué HJ, Madias NE, The challenge of hyponatremia. J Am Soc Nephrol., 2012; 23(7): 1140-1148.

37. Buffington MA, Abreo K, Hyponatremia: A Review. Intensive Care Med., 2015; 31(4): 223-236. 
38. Hoorn EJ, Zietse R. Diagnosis and Treatment of Hyponatremia: Compilation of the Guidelines. $J$ Am Soc Nephrol., 2017; 28(5): 1340-1349.

39. Zhang X, Li X, Prevalence of hyponatremia among older inpatients in a general hospital. Eur Geriatr Med., 2020; 1-8.

40. Clayton JA, Rodgers S, Blakey J, Avery A, Thiazide diuretic prescription and electrolyte abnormalities in primary care. Br J Clin Pharmacol., 2006; 61(1): 87-95.

41. Viramontes TS, Truong H, Linnebur SA, Antidepressantinduced hyponatremia in older adults. Consult Pharm., 2016; 31(3): 139-150.

42. Rodenburg EM, Hoorn EJ, Ruiter R, Lous JJ, Hofman A, Uitterlinden AG, Stricker BH, Visser LE, Thiazideassociated hyponatremia: a population-based study. Am J Kidney Dis., 2013; 62(1): 67-72.

43. Diaconu CC, Drăgoi CM, Bratu OG, Neagu TP, Pantea Stoian A, Cobelschi PC, Nicolae AC, Iancu MA, Hainăroșie R, Stănescu AMA, Socea B, New approaches and perspectives for the pharmacological treatment of arterial hypertension. Farmacia, 2018; 66(3): 408-415.

44. Furst H, Hallows KR, Post J, Chen S, Kotzker W, Goldfarb S, Ziyadeh FN, Neilson EG, The urine/plasma electrolyte ratio: a predictive guide to water restriction. Am J Med Sci., 2000; 319(4): 240-244.

45. Giordano M, Ciarambino T, Castellino P, Malatino L, Cataliotti A, Rinaldi L, Paolisso G, Adinolfi LE, Seasonal variations of hyponatremia in the emergency department: Age-related changes. Am J Emerg Med., 2017; 35(5): 749-752.

46. Liamis G, Milionis H, Elisaf M, A review of druginduced hyponatremia. Am J Kidney Dis., 2008; 52(1): 144-153.

47. Lu X, Wang X. Hyponatremia induced by antiepileptic drugs in patients with epilepsy. Exp Opin Drug Saf., 2017; 16(1): 77-87.

48. Gandhi S, McArthur E, Mamdani MM, Hackam DG, McLachlan RS, Weir MA, Burneo JG, Garg AX, Antiepileptic drugs and hyponatremia in older adults: two population-based cohort studies. Epilepsia, 2016; 57(12): 2067-2079.

49. Vachharajani TJ, Zaman F, Abreo KD, Hyponatremia in critically ill patients. J Intens Care Med., 2003; 18(1): 3-8.

50. Anpalahan $\mathrm{M}$, Chronic idiopathic hyponatremia in older people due to syndrome of inappropriate antidiuretic hormone secretion (SIADH) possibly related to aging. J Am Geriatr Soc., 2001; 49(6): 788-792.

51. Marinescu SA, Bejinariu CG, Giuglea C, Research Related to Breast Implant-associated Anaplastic Large Cell Lymphoma and its Influence on the DecisionMaking Process Related to Reconstructive Techniques Analysis of a series of cases and literature review. Mater Plast., 2019; 56(1): 229-234.

52. Ishikawa S, Saito T, Fukagawa A, Higashiyama M, Nakamura T, Kusaka I, Nagasaka S, Honda K, Saito T, Close association of urinary excretion of aquaporin-2 with appropriate and inappropriate arginine vasopressindependent antidiuresis in hyponatremia in elderly subjects. J Clin Endocrinol Metab., 2001; 86(4): $1665-1671$
53. Oelkers W, Hyponatremia and inappropriate secretion of vasopressin (antidiuretic hormone) in patients with hypopituitarism. N Engl J Med., 1989; 321(8): 492-496.

54. Boykin J, DeTorrente' A, Erickson A, Robertson G, Schrier RW, Role of plasma vasopressin in impaired water excretion of glucocorticoid deficiency. J Clin Invest., 1978; 62(4): 738-744.

55. Hammami MM, Almogbel F, Hammami S, Faifi J, Alqahtani A, Hashem W, Acute severe hypothyroidism is not associated with hyponatremia even with increased water intake: a prospective study in thyroid cancer patients. BMC Endocr Disord., 2013; 13(1): 27.

56. Kim MI. Hypothyroidism in the elderly. In: De Groot LJ, Chrousos G, Dungan K, et al., editors. Endotext. South Dartmouth, MA: 2000

57. Liamis G, Filippatos TD, Liontos A, Elisaf MS, Management of endocrine disease: hypothyroidismassociated hyponatremia: mechanisms, implications and treatment. Eur J Endocrinol., 2017; 176(1): R15-R20.

58. Kortenoeven ML, Sinke AP, Hadrup N, Trimpert C, Wetzels JFM, Fenton RA, Deen PMT, Demeclocycline attenuates hyponatremia by reducing aquaporin-2 expression in the renal inner medulla. Am J Physiol Renal Physiol., 2013; 305(12): F1705-F1718.

59. Berl T, Rastegar A, A patient with severe hyponatremia and hypokalemia: osmotic demyelination following potassium repletion. Am J Kidney Dis., 2010; 55(4): 742-748.

60. Decaux G, Waterlot Y, Genette F, Mockel J, Treatment of the syndrome of inappropriate secretion of antidiuretic hormone with furosemide. $N$ Engl $J$ Med., 1981; 304: 329-330.

61. Decaux G, Soupart A, Vassart G, Non-peptide argininevasopressin antagonists: the vaptans. The Lancet, 2008; 371(9624): 1624-1632.

62. Soupart A, Ngassa M, Decaux G, Therapeutic relowering of the serum sodium in a patient after excessive correction of hyponatremia. Clin Nephrol., 1999; 51(6): 383-386.

63. Habib S, Boyer TD, Vasopressin V2-receptor antagonists in patients with cirrhosis, ascites and hyponatremia. Therap Adv Gastroenterol., 2012; 5(3): 189-197.

64. Bowman BT, Rosner MH, Lixivaptan - an evidencebased review of its clinical potential in the treatment of hyponatremia. Core Evid., 2013; 8: 47-56.

65. Lehrich RW, Greenberg A, Hyponatremia and the use of vasopressin receptor antagonists in critically ill patients. J Intensive Care Med., 2012; 27(4): 207-218.

66. Robertson GL, Vaptans for the treatment of hyponatremia. Nat Rev Endocrinol., 2011; 7(3): 151-161.

67. Hline SS, Pham PT, Pham PT, Aung MH, Pham PM, Pham PC, Conivaptan: a step forward in the treatment of hyponatremia?. Ther Clin Risk Manag., 2008; 4(2): 315-326.

68. De Vecchis R, Noutsias M, Ariano C, Cesaro A, Cioppa C, Giasi A, Maureae N, Does Accidental Overcorrection of Symptomatic Hyponatremia in Chronic Heart Failure Require Specific Therapeutic Adjustments for Preventing Central Pontine Myelinolysis? J Clin Med Res., 2017; 9(4): 266-272. 
69. Brunner JE, Redmond JM, Haggar AM, Kruger DF, Elias SB, Central pontine myelinolysis and pontine lesions after rapid correction of hyponatremia: a prospective magnetic resonance imaging study. Ann Neurol., 1990; 27(1): 61-66.

70. Gheorghiade M, Konstam MA, Burnett JCJr, Grinfeld L, Maggioni AP, Swedberg K, Udelson JE, Zannad F, Cook T, Ouyang J, Zimmer C, Orlandi C, Efficacy of Vasopressin Antagonism in Heart Failure Outcome Study With Tolvaptan (EVEREST) Investigators, Short term clinical effects of tolvaptan, an oral vasopressin antagonist, in patients hospitalized for heart failure: The EVEREST Clinical Status Trials. JAMA., 2007; 297: 1332-1343.

71. Sullivan JK, Irrgang JJ, Losina E, Safran-Norton C, Collins J, Shrestha S, Selzer F, Bennell K, Bisson L, Chen AT, Dawson CK, Gil AB, Jones MH, Kluczynski MA, Lafferty K, Lange J, Lape EC, Leddy J, Mares AV, Spindler K, Turczyk J, Katz JN, TeMPO trial (treatment of meniscal tears in osteoarthritis): rationale and design features for four arms randomized controlled clinical trial. BMC Musculoskelet Disord., 2018; 19(1): 429.

72. Schrier RW, Gross P, Gheorghiade M, Verbalis JG, Czerwiec FS, Orlandi C, for the SALT Investigators. Tolvaptan, a selective oral vasopressin V2-receptor antagonist, for hyponatremia. $N$ Engl J Med., 2006; 355: 2099-2112.

73. Rozen-Zvi B, Yahav D, Gheorghiade M, Korzets A, Leibovici L, Gafter U, Vasopressin receptor antagonists for the treatment of hyponatremia: Systematic review and meta-analysis. Am J Kidney Dis., 2010; 56: 325-337.

74. Verbalis JG, AVP receptor antagonists as aquaretics: review and assessment of clinical data. Cleve Clin J Med., 2006; 73(3): S24-S33.

75. www.ema.europa.eu/en/documents/product-infor mation/samsca-epar-product-information_en.pdf

76. Gross PA, Wagner A, Decaux G, Vaptans are not the mainstay of treatment in hyponatremia: perhaps not yet. Kidney Int., 2011; 80(6): 594-600.

77. Gheorghiade M, Gottlieb SS, Udelson JE, Konstam MA, Czerwiec F, Ouyang J, Orlandi C, Tolvaptan Investigators, Vasopressin $\mathrm{v}(2)$ receptor blockade with tolvaptan versus fluid restriction in the treatment of hyponatremia. Am J Cardiol., 2006; 97(7): 10641067.

78. Nemerovski C, Hutchinson DJ, Treatment of hypervolemic or euvolemic hyponatremia associated with heart failure, cirrhosis, or the syndrome of inappropriate antidiuretic hormone with tolvaptan: a clinical review. Clin Ther., 2010; 32(6): 1015-1032.

79. Siegel AJ, Hyponatremia in psychiatric patients: update on evaluation and management. Harv Rev Psychiatry, 2008; 16(1): 13-24.

80. Gheorghiade M, Niazi I, Ouyang J, Czerwiec F, Kambayashi J, Zampino M, Orlandi C, Tolvaptan Investigators. Vasopressin V2-receptor blockade with tolvaptan in patients with chronic heart failure: Results from a double-blind, randomized trial. Circulation, 2003; 107: 2690-2696.
81. Gheorghiade M, Gattis WA, O'Connor CM, Adams KFJr, Elkayam U, Barbagelata A, Ghali JK, Benza RL, McGrew FA, Klapholz M, Ouyang J, Orlandi C, Acute and Chronic Therapeutic Impact of a Vasopressin Antagonist in Congestive Heart Failure (ACTIV in CHF) Investigators, Effects of tolvaptan, a vasopressin antagonist, in patients hospitalized with worsening heart failure: A randomized controlled trial. JAMA., 2004; 291: 1963-1971.

82. Soiza RL, Cumming K, Clarke JM, Wood KM, Myint PK, Hyponatremia: Special Considerations in Older Patients. J Clin Med., 2014; 3(3): 944-958.

83. Udelson JE, Orlandi C, Ouyang J, Krasa H, Zimmer CA, Frivold G, Haught WH, Meymandi S, Macarie C, Raef D, Wedge P, Konstam MA, Gheorghiade M, Acute hemodynamic effects of tolvaptan, a vasopressin V2 receptor blocker, in patients with symptomatic heart failure and systolic dysfunction: An international, multicenter, randomized, placebo-controlled trial. $J$ Am Coll Cardiol., 2008; 52: 1540-1545.

84. Ghali JK, Koren MJ, Taylor JR, Brooks-Asplund E, Kaisheng F, Long WA, Smith N, Efficacy and safety of oral conivaptan: a V1A/V2 vasopressin receptor antagonist, assessed in a randomized, placebo-controlled trial in patients with euvolemic or hypervolemic hyponatremia. J Clin Endocrinol Metab., 2006; 91: 2145-2152.

85. Abraham WT, Aranda JM, Boehmer JP, Elkayam U, Gilbert EM, Gottlieb SS, Hasenfu $\beta$ G, Kukin M, Lowes BD, O'Connell JB, Tavazzi L, Feldman AM, Ticho B, Orlandi C, Rationale and Design of the Treatment of Hyponatremia Based on Lixivaptan in NYHA Class III/IV Cardiac Patient Evaluation (THE BALANCE) Study. Clin Transl Sci., 2010; 3(5): 249-253.

86. Soupart A, Gross P, Legros JJ, Alföldi S, Annane D, Heshmati HM, Decaux G, Successful long-term treatment of hyponatremia in syndrome of inappropriate antidiuretic hormone secretion with Satavaptan (SR121463B), an orally active non-peptide vasopressin V2-receptor antagonist. Clin J Am Soc Nephrol., 2006; 1: 1154-1160.

87. Gines P, Wong F, Watson H, Milutinovic S, del Arbol LR, Olteanu D, HypoCAT Study Investigators, Effects of satavaptan, a selective vasopressin V2 receptor antagonist, on ascites and serum sodium in cirrhosis with hyponatremia: a randomized trial. Hepatology, 2008; 48: 204-213.

88. Yamaguchi K, Shijubo N, Kodama T, Mori K, Sugiura T, Kuriyama T, Kawahara M, Shinkai T, Iguchi H and Ectopic ADH Syndrome Therapeutic Research Group, Clinical implication of the antidiuretic hormone (ADH) receptor antagonist mozavaptan hydrochloride in patients with ectopic ADH syndrome. Jpn J Clin Oncol., 2011; 41: 148-152.

89. Luengo-Fernande R, Leal J, Gray A, Dementia 2010: The Economic Burden of Dementia and Associated Research in the United Kingdom; Alzheimer's Research Trust: Oxford, UK, 2010 